\section{Artigo Livre}

${ }^{*}$ Recebdio em: 20.04.2017. Aprovado em: 21.08 .2017

** Pesquisadora associada ao ECSAS Doutora em Ciências Sociais pela Universidade Federal da Bahia (2017); e atualmente realiza seu Pós(2017); e atualmente realiza seu Pós-
doutorado (PNPD/CAPES) em Estudos da Tradução na Universidade de Brasília. Email: danifelixcm@gmail.com

\title{
Controvérsias no mundo da performance art: um relato de
} pesquisa"

Controversies in the world of performance art: a research report Daniela Félix Carvalho Martins ${ }^{* * *}$

Resumo: fundamentado em pesquisa desenvolvida no doutorado, o texto tem por objetivo apresentar a arte da performance realizando-se e permanecendo no mundo através de um fluxo de interações entre artistas, públicos, produtores, políticas públicas, espaços tradicionais (galerias e museus) e não tradicionais de arte (ruas, espaços públicos em geral). Realização e permanência referindo-se à sustentação da performance numa duração como evento ao vivo e também aos modos em que ela continua operando, mediante seus registros em fotos, vídeo, instruções escritas, vestígios materiais etc. Esses elementos foram reunidos em trabalho de pesquisa empírica principalmente no Brasil, mas em breves períodos no Chile e Peru, e posteriormente, em Londres, onde foi mais extenso o tempo dedicado ao trabalho de pesquisa, que em sua maior parte consistiu em pesquisa documental, na LADA - Live Art Development Agency. Palavras-chaves: performance art; live art; arte contemporânea; sociologia da arte; sociologia associativa
Abstract: based on research developed in the $\mathrm{PhD}$, the paper aims to present performance art both in its being held and remaining in the world via a collaborative flow between actors, artists, audiences, producers, public policy, and both traditional (e.g. galleries and museums) and non-traditional (e.g. streets and public spaces in general) art spaces. The terms to hold and remain are used both in the sense of its being sustained throughout a duration as a live event, and its longevity through traces such as photos, videos, written instructions and its material remains etc. These elements were gathered into an empirical research study, realized mainly in Brazil, but also during brief periods in Chile and Peru, and later in London, where the time devoted to research was more extensive, mostly consisting of documentary research at LADA - Live Art Development Agency.

Keywords: performance art; live art; contemporary art; sociology of art; associative sociology 


\section{Introdução}

A pesquisa buscou compreender os processos contemporâneos de realização e permanência da arte da performance. Para isso, foram considerados os elementos heterogêneos - artistas, públicos, produtores culturais, editais públicos, instituições, regimes jurídicos e mercado de arte - que se associam nesses processos de realização e permanência. Assim é que, embora a pesquisa coloque já de partida um problema teórico a realização e permanência de uma arte efêmera - o modo de avançar pelos desdobramentos desse problema se fez através do desenvolvimento de uma pesquisa empírica, que permitisse a convivência com essa heterogênese do fazer performático.

A pesquisa empírica foi realizada através de uma inserção prévia da pesquisadora no mundo da arte da performance. Desde o ano 2009, faço parte de um coletivo de artistas, o Coletivo OSSO, fundado na cidade de Salvador, Bahia, nesse mesmo ano. Além de tentativas de execuções de ações performáticas (que terminei por abandonar), minha participação no Coletivo tem sido diretamente vinculada a atividades de curadoria e de organização de Mostras. Essa inserção me permitiu um contato com as múltiplas realidades e atividades demandadas no processo de realização e permanência do fazer performático. Durante esses anos de atuação, o OSSO realizou diversos eventos voltados para essa forma artística, também sendo convidado a participar de outros eventos organizados por outros coletivos, como o grupo Corpos Informáticos, de Brasília. Além disso, os integrantes do OSSO são convidados ou selecionados para festivais, exposições e residências artísticas.

Entratanto, a MOLA (Mostra OSSO Latino-Americana de Performances) uma das principais atividades do Coletivo, realizada nos anos de 2010, 2013 e 2015, foi escolhida como campo empírico. Esta seleção deve-se ao fato de que, para a realização da Mostra, somam-se ao Coletivo outros profissionais do que se convencionou chamar "economia criativa": produtores culturais, jornalistas, fotógrafos, videomakers, designers, programadores de site, etc. O fato da Mostra ser realizada mediante edital público da Fundação Cultural do Estado da Bahia (FUNCEB) foi outra característica levada em consideração para privilegiar esta atividade, pois permitiu recolher novos coletivos nesse processo de realização e permanência.

Desse modo, a produção da MOLA propicou o acesso às realidades empíricas nas quais os atores envolvidos se ocupam da possível realização e permanência das performances - desde a submissão de projeto a edital público para captação de recursos, à logística de produção (que inclui a contratação de serviços de alimentação, hospedagens, transportes etc.), aos contatos com diferentes agentes públicos (funcionários de secretarias da cultura e polícias das três cidades que sediaram os eventos), até as instabilidades nas ações performáticas e às reações das audiências

Essas instabilidades podem ser relacionadas a um certo descompasso entre as "expectativas estéticas" e as propostas artísticas contemporâneas, como afirmou Nathalie Heinich: 
Existe, enfim, uma terceira razão para tal escassez dos argumentos estéticos: para que o critério de beleza seja aplicado a uma obra de arte, é preciso pelo menos que esta seja considerada como tal, isto é, que ela apresente as características canônicas de uma pintura ou de uma escultura. Mas desde que estas estejam ausentes, como ocorre amiúde na arte contemporânea, o espectador tem apenas duas soluções: 1) aceitar redefinir as fronteiras do que é ou não artístico, alargando-as sob o risco de se deixar enganar ao admirar ou adquirir objetos sem valor, e de negligenciar, ao mesmo tempo, o trabalho dos autênticos artistas; 2) recusar o que transgride as fronteiras constituídas pela tradição, sob o risco de ignorar as tentativas que a posteridade reconhecerá como autênticas e mesmo geniais (caso típico do "efeito Van Gogh"). A questão pertinente deixa então de ser a questão da beleza do objeto e passa a ser a de sua natureza, artística ou não (HEINICH, 2011, p. 80)

Nas dinâmicas desenvolvidas pelo Coletivo OSSO, assim como nas realizações da MOLA, estavam ausentes actantes relacionados aos espaços institucionalizados de arte, a exemplo de galerias, museus e do mercado de arte no sentido estrito, isto é transações de compra e venda de ações performáticas, no caso. Estas ausências levaram ao deslocamento da pesquisa para uma segunda etapa que teve lugar em Londres, durante meu doutorado sanduíche financiado pela CAPES, de julho de 2015 a maio de 2016.

Seguindo a orientação do Prof. Simon Bayly no período do doutorado sanduíche, realizei em Londres, além de observações em galerias e museus, uma pesquisa documental no acervo da LADA
(Live Art Development Agency), agência sediada nesta cidade e especializada no desenvolvimento de atividades no universo da performance (Live Art, no Reino Unido). A análise documental privilegiou o acervo da revista Performance Magazine, tida como única fonte documental das realizações performáticas nas décadas de 70 e 80 no Reino Unido, e considerada por pesquisadores como elemento fundamental para compreender o processo de institucionalização dessa forma artística. Além desse acervo, os dados coletados indicaram que a emergência da LADA foi outro aspecto fundamental nesse processo de institucionalização, no sentido de estabilizar algumas controvérsias recorrentes no que dizia respeito ao frágil estatuto dessa prática enquanto arte, e sua possível circulação nos meios artísticos.

Assim, nesses processos de realização e permanência, identificamos um fluxo de instabilidades/estabilidades, que levou a uma tipologia, esta funcionando para a caracterização das ocorrências empíricas da pesquisa. Primeiramente, o referido fluxo foi observado na diversidade de termos que a performance pode assumir: Body art, Live art, Art charnel, Art corporel, Specimen art, Hardship art, Assemblage, Ordeal art, Arte de acción (PEIXOTO, 2008), Arte efêmera. Esta variedade aponta, por um lado, para a estabilização de certos modos de realização; por outro, indica uma instabilidade, devida à mesma multiplicidade que esse fazer artístico assume. Uma outra característica desse fluxo é observável pelo tipo de ligação entre artista e evento performático: para que uma arte seja exibida e/ou comercializada, a independência da obra em relação ao 
${ }^{1}$ Actante é um conceito que Bruno Latour retoma da semiótica de Greimas e da pragmática da linguagem de J. L. Austin, para lida com uma equivalência (simetria) de elementos heterogêneos, porque és um ter que permite designar uma pessoa, um animal, um instrumento, uma máquina etc. Assim, um actante pode ser qualquer pessoa, instituição ou coisa que tenha agência, isto é, produza efeitos no mundo e a partir do mundo. Há grande diferença entre os conceitos de actante e de ator no sentido sociológico tradicional. $\mathrm{O}$ "ator" é compreendido a partir da noção de fonte de ação atribuída a um humano ou uma estrutura social. Um actante é definido, na obra de Latour, pela heterogeneidade de sua composição; é uma dupla articulação entre humanos e não-humanos cuja construção se faz em rede, ou seja através de associações.

${ }^{1}$ A relatabilidade, conceito oriundo da Etnometodologia, é a propriedade que permite que os atores tornem o mundo visível a partir de suas ações, fazendoas compreensíveis e transmissíveis. artista parece uma condição fundamental; mas este atrelamento surge de modo variável na performance. Ainda, como um outro aspecto característico desse fluxo de instabilidade/estabilidade está a relação artista/público/coisas no evento performático: esta tem o risco à sua espreita, porque a performance não propicia e nem busca uma execução controlada, mas há sempre uma imprevisibilidade, na qua se incluem participações inesperadas de pessoas e/ou coisas. Esse risco pode levar até à não-realização da performance.

Apesar desse eixo de instabilidade, é nítido um processo corrente de estabilização do qual não se pode hoje prever o fim. Nas últimas décadas a arte performance tem sido acolhida nos principais museus e galerias de arte; o volume de pesquisas sobre esta forma artística tem crescido exponencialmente; a presença da performance nas principais feiras e bienais de arte já não é nenhuma novidade; e as dinâmicas de compra e venda de ações performáticas vêm se desenvolvendo.

O que há de certo é somente a não-centralidade do artista no transcorrer da situação. Essa característica destaca o faze performático como profundamente experimental ou cosmopolítico (STENGER, 2005a), isto é, como um fazer que envolve relações simetricamente comparáveis entre coletivos muito distintos entre si, mas só aparentemente inconciliáveis no plano da análise. Em outras palavras, as situações performáticas enquanto interações são sempre abertas às retomadas de ações de outros durante a realização, não é completada e fechada pela ação humana, mas as coisas participam das situações a partir do que permitem fazer, e fazem das e nas situações uma assembléia entre ações humanas e ações das coisas, isto é, uma heterogênese. Desse modo, os "objetos" não valem por s só, mas também não o valem os artistas e o público. A performance é aberta no sentido de uma cosmopolítica como afirmou Stengers (2005b), isto é, uma interação na qual as ações não têm um centro, não mais atribuídas a um único ator que age, antes o termo cosmopolítica quer revelar a pluralidade de elementos que participam e resultam das interações, como também o reconhecimento das entidades que contam nas interações a partir dos efeitos que nelas produzem. Daí a necessidade de incluir a multiplicidade dos atores, ou melhor, dos $\operatorname{actantes}^{1}$ para o conhecimento buscado nesta pesquisa. Consequentemente, observamos que este fluxo de instabilidade/estabilidade, fruto da condição circunstancial e efêmera desse fazer artístico, move-se com a ação de diferentes atores/actantes. Estes, através de suas articulações, associações e mediações, habilitam uma relatabilidade ${ }^{2}$ de redes de produção/transformação - o que também pode propiciar permanência da forma performance.

\section{Fazendo redes invisíveis}

Na produção da MOLA existe uma etapa denominada "visita técnica", cujo objetivo é organizar a infraestrutura para a Mostra: contratar serviços de hospedagem e alimentação, formalizar apoios institucionais, realizar divulgação prévia, etc. Trata-se da construção de uma rede de ações que possibilite a passagem da Mostra do projeto à execução. Em outras palavras, para que as pesquisas dos artistas, apresentação de suas performances, exibição de vídeos nas

Dossiê Práticas e Políticas Culturais: Paradoxos e diálogos com a tecnologia

Arquivos do CMD, Volume 5, N.1. Jan/Jul 2017 
${ }^{3}$ Responsável pela empresa de produção cultural Baluart, produtora da MOLA vias públicas sejam realizadas, um trabalho prévio de produção é exigível; é o que vai delinear as ações que permitirão a correspondência entre o que está estabelecido no orçamento apresentado à FUNCEB e a contratação dos serviços. É preciso que o orçamento seja suficiente. E o recurso disponibilizado pelo edital público resulta em montantes muitas vezes abaixo do valor de mercado, solicitando uma habilidade de negociação dos organizadores e produtores.

Durante o período da "visita técnica" foram feitas anotações diárias sobre as atividades realizadas. Nem todas foram registradas, porque algumas vezes essa prática se tornava difícil; é frequente que as atividades de produção sejam pouco perceptíveis. Assim, em conversa com a produtora Fernanda Félix ${ }^{3}$ durante a $3^{\mathrm{a}}$ edição da Mostra que teve lugar na cidade de Lençóis (2015), ela relatou que o trabalho de produção deve ser "invisível” em qualquer evento artístico; para ela, o bom trabalho de produção se define como aquele que não aparece: (...) isso quer dizer que não houve problemas na estratégia montada, é como o trabalho do zagueiro numa partida de futebol, se ele foi bem, o time ganhou, ninguém fala do zagueiro. Um atacante pode ter jogado mal a partida toda, mas se ele fizer um gol é herói. (Fernanda Félix, entrevista, 2015)

De qualquer maneira, os registros escritos em campo foram o modo mais eficiente para apreensão das redes de ações que antecedem a realização da Mostra (ou de boa parte delas). Numa entrevista posterior que fiz no mesmo ano de 2015 com Fernanda Félix, já em Salvador, ela relatou duas situações durante a produção de um outro evento em que havia participado, a 3 a Bienal da Bahia, que aconteceu entre os dias 29 de maio a 7 de setembro de 2014 Essas situações vivenciadas por ela ocorreram durante a construção da "Galeria Esteio", idealizada pelo artista baiano Maxim Malhado na Escola de Belas Artes da UFBA, e na produção da performanceinstalação do artista libanês Charbel-Joseph H. Boutros. Segue o relato, que dá bem uma ideia do trabalho de produção - e de como ele afeta, e pode afetar decisivamente, uma obra.

Fernanda Félix - Então o processo da Galeria Esteio foi uma instalação idealizada pelo artista Maxim Malhado, ele propunha que a gente fizesse três galerias de casa de taipa sabe?! Eram três casas de taipas, essa idealização de Maxim na verdade já havia sido feita outra vez, ele reproduziu na Bienal, e isso foi inspirado na região dele de Sítio Novo, que lá as casas de taipa são bem comuns, o artista escolheu reproduzir isso na Escola de Belas Artes da UFBA, onde caberiam perfeitamente as três casas de taipa A gente fazia uma epécie de deslocamento da região de Sítio Novo, que é ali, distrito de Alagoinhas na Bahia. Pra fazer isso, a gente teria que utilizar os materias de lá de Sítio Novo, o barro de lá , as varas de madeira para fazer a estrutura da casa também de lá de Sítio Novo. Nas primeiras viagens de carreto que fizemos, nós retiramos uma quantidade de barro a partir do cálculo dele e do pedreiro, que também era de Sítio Novo, e que daria [o cálculo] para montar as três casas na EBA [Escola de Belas Artes]; então a gente foi lá pra trazer o barro e essas madeirinhas com que se constroem as casa de taipa. E aí trouxemos o pedreiro, que também trouxe outros pedreiros de lá, ficaram todos alojados dormindo na Escola de Belas Artes, num 
espaço que a gente coseguiu lá e, em poucos dias, menos de dez dias, a gente conseguiu construir as três casa de taipa. Só que mais ou menos no sexto dia da construção, o pedreiro de Maxim Malhado nos falou que precisari de mais barro do que a gente havia levado do que ele tinha dito, então precisava de mais barro e mais madeiras, então a gente teve que providenciar mais madeiras em Sítio Novo e mais barro. Mas não era possível na região, o barro que a gente queria ia demorar demais, então a gente teve que buscar alterntivas para completar as casas com o barro, daí a gente foi pesquisar tudo isso e descobriu que conseguiria comprar barro e alugar o carreto para trazer esse barro lá no Litoral Norte, perto de Camaçari, na verdade. Então o que era para ser feito só com essa matéria-prima de Sítio Novo não foi bem assim, no final teve de fazer de outra maneira... a solução que a produção ofereceu foi de outra maneira, inclusive saiu mais em conta e saiu mais rápido e permitiu que a gente concluísse um dia antes do prazo.

A outra instalação artística era uma proposta do artista Charbel, que a idealização dele...porque ele ficou também residente no Sacatá, uma residência artística na Ilha de Itaparica. A proposta dele era trazer a água da bica de Itaparica num recipiente, esse recipiente seria uma espécie de contêiner quadrado flutuante com uma torneira. Então botaria a água de Itaparica dentro desse contêiner, dessa caixa metálica, digamo assim, e aí fizemos um cálculo. A água seri gotejada, por essa torneira. Iria secar no fim da Bienal. Então no início da Bienal abriríamos a torneira, iniciando gotejamento, e a última gota cairia no final gotejamento, e a última gota cairia no final
dos cem dias da Bienal. Essa estrutura flutuante seria colocada no mar perto do MAM. Então a gente foi atrás de produzir isso daí. Fazer a caixa, como seria trazer essa água da bica de Itaparica para encher essa estrutura era bastante água inclusive, pegar o caminhão munck para poder carregar essa caixa metálica e botar no mar. Enfim, fiz todo um orçamento, um estudo de viabilidade e tal, e concluímos que na verdade o que tornava a performance insustentável era o fato de termos que levar um caminhão pipa daqui de Salvador, porque não se alugava isso lá em Itaparica. Para, em Itaparica, bombear a água da bica e encher o caminhão, esse caminhão pipa voltar para Salvador para, então, encher esse contêine que com o caminhão munck seria colocado no mar perto do MAM. Isso facaria caríssimo isso precisaria de algumas viagens. E aí, em conversas com toda a equipe operacional, inclusive nossos fornecedores de caminhão pipa etc., percebeu-se que se a gente simplesmente alugasse uma diária do caminhão pipa e esse caminhão pipa retirasse a água do mar e essa mesma água alimentasse o container que já estaria na posição final dele, isso se tornaria viável. A proposta de Charbel era que misturasse as águas ao traze a água de Itaparica... mas a Bienal tinha uma verba restrita e poucos dias para produção, é.. isso ficou a cargo da curadoria da Bienal decidir, mas a produção tinha oferecido esta solução... botar uma outra água, água daqui mesmo, do mar perto do MAM.

A solução oferecida pela equipe de produção foi acatada pela curadoria e o contêiner de Charbel foi levado adiante pela ação de outros profissionais. Como foi dito antes, o caráter experimental dessas práticas artísticas envolve um fluxo de interações e um risco de não realização. Desde os ready-made de Marcel Duchamp e na arte conceitual, os trabalhos artísticos se apropriam de objetos não

Dossiê Práticas e Políticas Culturais: Paradoxos e diálogos com a tecnologia

Arquivos do CMD, Volume 5, N.1. Jan/Jul 2017 
necessarimente manufaturados pelos artistas, como também contam com a participação de outras pessoas e profissionais no processo de realização. Entretanto, num sentido ainda mais geral, Howard Becker (1974) considerou que qualquer forma artística, mesmo as formas convencionais, se realiza através da cooperação de diversas atividades.

Pense, com relação a qualquer obra de arte, em todas as atividades que devem ser realizadas para que o trabalho apareça, como finalmente aparece. Para uma orquestra sinfônica dar um concerto, por exemplo, os instrumentos devem ter sido inventados, fabricados e mantidos, uma notação deve ter sido concebida, e música composta usando essa notação, as pessoas devem ter aprendido a tocar as notações sobre os instrumentos, períodos e espaços para ensaio devem ter sido estabelecidos, publicidade organizada e bilhetes vendidos, e um público capaz de ouvir, e de alguma forma compreender e responder à performance [desempenho], deve ter sido recrutado. Uma lista semelhante pode ser compilada para qualquer uma das artes do espectáculo. Com pequenas variações (substituição de materiais por instrumentos, e exibição por performance), a lista aplica-se às artes visuais e literárias (substituição de linguagem e impressão por publicação para exposição). De um modo geral, as atividades necessárias incluem tipicamente conceber a ideia para o trabalho, criar os artefactos físicos necessários, criar uma linguagem de expressão convencional, formar pessoal artístico e audiências para usar a linguagem convencional para criar e experimentar, fornecer a mistura necessária desses ingredientes para um determinado trabalho ou performance [execução].”(Becker, p.767 [Tradução nossa])

Seguindo a compreensão de Becker, podemos afirmar que a obra de arte é uma reunião de interações, uma prática que ao mesmo tempo retoma outras práticas, assim como através dessas segue adiante. Por outro lado, adicionando à constatação desse autor, é possível afirmar que a estabilização de certas formas artísticas (pintura, escultura, música, etc) também se deve a esse fato de que redes de interações prévias garantem sua estabilização e, como consequência, a ausência de cooperações prévias pode produzir a instabilidade de outras formas artísticas como é o caso da arte da performance. Como já indicado acima, tentamos reconstruir situações de pesquisa que indicam esse aspecto. Seguem trechos de meu diário de campo:

Acabo de chegar à hospedagem para a visita técnica, em minha companhia Rose Boaretto Fernanda Félix. Cansaço. Faltam quinze dias para o início da MOLA - Mostra OSSO Latino- Americana de Performances. Chegamos às oito horas na rodoviária de Porto Seguro depois de uma exaustiva viagem de setecentos e catorze quilômetros desde Salvador. Não há tempo para descanso; com mochilas nas costas, tomamos um táxi seguimos diretamente para a Secretaria Municipal de Turismo e Cultura. Um pequeno tempo de espera nos aguardava, mas fomos por fim recebidas de maneira acolhedora pelos técnicos. O secretário viajara a trabalho, na tentativa de garantir a inserção de Porto Seguro como cidade de apoio para a Seleção de Portugal durante a Copa do Mundo de Futebol 2014. Os técnicos da Secretaria tinham autorização para atender algumas de

Dossiê Práticas e Políticas Culturais: Paradoxos e diálogos com a tecnologia

Arquivos do CMD, Volume 5, N.1. Jan/Jul 2017 
nossas demandas, entre elas apoio para eventos culturais. Nosso principal objetivo era conseguir um apoio da Secretaria para transportes na rota Arraial d'Ajuda Trancoso, distritos de Porto Seguro. De Arraial a Trancoso, são dezessete quilômetro por estrada de barro e trinta quilômetros pela estrada pavimentada. Solicitávamos o apoio da Prefeitura para um deslocamento po barco, que dura cerca de uma hora, entre esses distritos, para podermos observar melhor mais longamente as paisagens locais, seus recortes, relevos, vegetação etc. vistos do mar. Pedíamos também dois trechos a serem realizados de ônibus (Arraial/Trancoso Trancoso/Arraial). Era também preciso informar as autoridades locais sobre a data da realização do evento, a fim de evitar transtornos futuros com policiais ou agentes do patrimônio histórico.

Apresentamos o projeto, informando que se ratava de um evento patrocinado pela Secretaria do Estado da Bahia através de edital público. Surgiram as perguntas que já prevíamos

* O que é um festival de performance?

* Outro nome para festival de teatro de rua?

* É circo?

A produtora abriu, então, seu computador e passou a apresentar os registros fotográficos da primeira edição realizada em Salvador no ano de 2010. Durante a exibição dos registros, eu e Rose Boaretto tratávamos de esclarecer dúvidas sobre essa imprecisa forma artística e apresentar a proposta curatorial dessa segunda edição. Por exemplo, Rose explicou que pretendíamos "que os artistas convidado produzam suas performances a partir do contexto de Arraial e Trancoso, utilizando materiais locais, realizando as performances na rua".
Um dos técnico disse que havia tomado contato com este tipo de arte quando esteve em Lisboa e Berlim: "Parece que havia festivais por lá, performance por toda parte". Entusiasmado, ele ouvia atentamente a apresentação do projeto; os demais pareciam acompanhar o que se passava a partir de seu entusiasmo. A reunião durou cerca de três horas e a conversa foi extremamente amistosa, superou nossas expectativas iniciais.

Em seguida, fomos em direção à balsa que nos levaria para Arraial d'Ajuda. Não esperávamos uma cama aconchegante na hospedagem, e isto se confirmou. Deixamos lá nossa bagagem e saímos para contratar o serviços de alimentação e hospedagem para o total dos integrantes da Mostra.

O cansaço começou a conjugar-se com ansiedade; esta etapa do processo, que eu julgava fácil, estava se revelando difícil e exaustiva. A distância de Salvador dificultava o trabalho; dispúnhamos de escasso recurso financeiro para essa visita técnica, o que aumentava nosso tempo de trabalho, na busca por hospedagem e alimentação adequadas ao orçamento; e tínhamos apenas três dias de prazo para regressar com as estratégias de alimentação e hospedagem montadas. Percorremos os restaurantes e hospedagens disponíveis, primeiro em Arraial e depois em Trancoso. Essas localidades são turísticas, oferecem uma diversidade de opções de restaurantes e pousadas; inicialmente, visitamos o maior restaurante de Arraial, imaginando que seria mais fácil conseguir apoio por parte de um estabelecimento de maior porte, o que não se verificou. $O$ proprietário desse estabelecimento era um homem simpático, sorridente, "bom de prosa"; conversamos com ele durante toda uma tarde, para ouvir dele, ao final, num tom imperioso: "Não tenho interesse". Respirei

Dossiê Práticas e Políticas Culturais: Paradoxos e diálogos com a tecnologia

Arquivos do CMD, Volume 5, N.1. Jan/Jul 2017 
${ }^{4}$ Sócia de Fernanda na empresa Baluart, também produtora da MOLA fundo para conter a irritação, o cansaço e a ansiedade. Para ele, habituado a apoia projetos de grandes emissoras de televisão, como Globo e SBT, nosso projeto não interessava (Caderno de campo 21/02/2013)

Diante dessas singularidades próprias da performance art, que se traduzem em obstáculos para sua realização e permanência no mundo, podemos ver que, embora a perspectiva de Howard Becker seja importante para compreender o complexo de atividades envolvidas nos trabalhos artísticos, ela não avança na direção de contemplar esse problema - artes como a música, o teatro e formas mais convencionais das artes visuais contam com esforços de estabilização anteriores, realizado por artistas, produtores, organizadores, negociantes, público, críticos, curadores e materiais convencionais como tela, pincéis, cenários, palcos, instrumentos musicais etc. Ainda que durante um longo período inicial, tenham se deparado com dificuldades similares.

Essas imprecisões da prática performática são muitas vezes tomadas como "amadorismo". E essa impressão equivocada é eventualmente fortalecida pelo uso que os artistas da performance fazem de objetos e tecnologias que não são criadas por eles, que tampouco têm habilidades de nível profissional para lidar com elas. O antropólogo Roger Sansi-Rocca (2015) comenta essa mesma característica, que também identificou em sua pesquisa:

Depois de Duchamp, a arte de vanguarda não propôs necessariamente novas técnicas ou habilidades artísticas per se (novas mídias, como diríamos hoje), mas a alteração do papel do artista de produtor qualificado com uma técnica particular, para um 'amador' não qualificado que encontra objetos, imagens, técnicas e pessoas. Isto é, podemos dizer que muitos artistas contemporâneos 'trabalham com’ filme, vídeo, som ou mídia digital, sem necessariamente serem cineastas ou profissionais de mídia - o que quer dizer, sem a pretensão de estar no controle das mídias que eles estão usando. Da mesma forma, os artistas trabalham com pessoas em projetos participativos e site-specific, sem a pretensão de ter as habilidades específicas, quer como cientistas sociais, ou assistentes sociais, mas apenas trabalhar a partir de sua própria experiência como seres sociais. (SANSIROCCA, 2015, p. 124 [Tradução nossa])

Dado que essas realizações artísticas não são fruto de um trabalho artesanal, no sentido de uma habilidade específica empregada numa manufatura, ainda segundo Sansi- Rocca, esses artistas adquirem um papel "executivo", no qual dirigem e organizam materiais produzidos por outros. Os produtores culturais, ao contrário, são profissionais de habilidade específica. Cabe a eles, também, traduzir as imprecisões dos artistas num modelo de ação plenamente claro e exequível, mediante a criação de ofícios, tabelas, cálculos, conhecimento das cláusulas dos editais públicos que permitem e limitam o remanejamento de verbas, transações bancárias, organização de recibos e notas fiscais etc., para garantir o sucesso das cooperações técnicas.

Prosseguindo: no retorno a Salvador as produtoras - Lívia ${ }^{4}$ e Fernanda - deveriam preparar diversos documentos para formalizar 
o apoio da Secretaria e dos serviços contratados. Seriam três ofícios: dois deles endereçados à Secretaria para solicitação referente aos transportes e um terceiro a ser encaminhado ao comando da Polícia Militar, informando as datas de realização do evento e o uso de via pública para as ações performáticas. Além dos ofícios, foram elaborados contratos dos serviços de hospedagem e alimentação e reunidas notas fiscais. Parte dessa documentação foi adicionada ao relatório final, na prestação de contas. A ação dessas "entidades que não dormem" (LATOUR, 2015) evitará a inadimplência do projeto. Assim, nessa cooperação técnica, não apenas são necessárias diferentes habilidades humanas, como o sucesso da cooperação técnica é comunicado pela ação delegada aos documentos comprobatórios. No “desenrolar artístico" essas cooperações enfrentarão um "teste de força”. Isto é, algumas experimentações performáticas podem chacoalhar os esforços de "invisibilização" das cooperções técnicas, adicionando-as aos fluxos de propiciação das

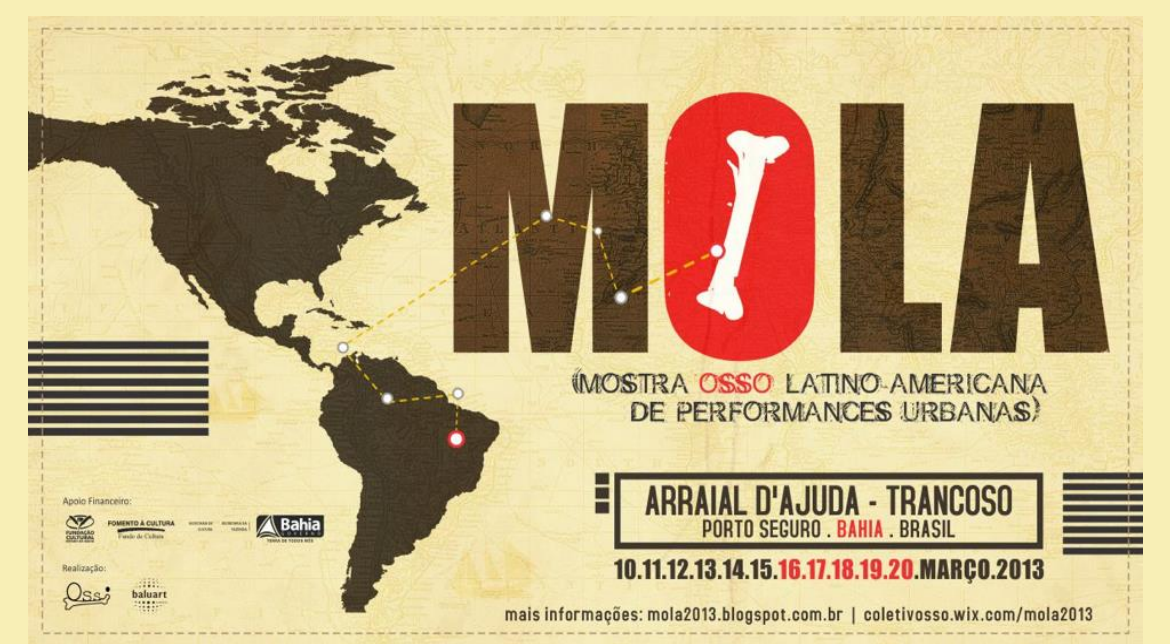

performances, durante o "desenrolar artístico".

Figura 1. Patrícia Simplicio. Imagem: Acervo MOLA Cartaz II MOLA Imagem: Acervo MOLA, 2013 II MOLA, Porto Seguro

A definição "profissionais de habilidade específica" pode também ser empregada para os agentes públicos que elaboram os editais e dos que realizam a auditoria das prestações de conta dos produtores culturais. Muitos desses agentes públicos não possuem familiaridade com os tipos de realizações artísticas contempladas pelos editais; não são eles, portanto, que avaliam o "mérito artístico" dos projetos submetidos. Todavia, esses agentes públicos conformam o "público" das operações dos produtores culturais, a performance chega até eles pelos registros da cooperação técnica, isto é, as tabelas, recibos, notas fiscais, etc. que garantem as realizações performáticas para os agentes públicos da FUNCEB. Essas entidades devem permitir que as performances realizadas durem e se expandam mais amplamente para encontrar mais participantes de sua rede: os agentes públicos.

O que a pesquisa empírica apresentada aqui revela é que, nesses esforços cooperativos não aparece nunca um quadro bem delimitado, nada que possa ser tomado como um "retrato", ou "frame", no sentido empregado pelo interacionismo simbólico. O que aparece é algo que podemos resumir, citando Latour, como uma rede contínua "muito ramificada, multiplicando pessoas, datas e lugares muito diferentes" (LATOUR, 2015, p. 168). Essa rede se expande sempre por outras interações, sempre se deslocando e por 
isso nunca produzindo um domínio bem delimitado. Como já vimos, as interações nas redes cooperativas contam com actantes diversos, não apenas com os profissionais de habilidade específica (produtores, agentes públicos etc.) e artistas, mas também com ofícios, contratos, notas fiscais, tabelas, etc. - entidades que operam não como meros meios para transmitir à obra as competências dos profissionais envolvidos, mas como mediadores, equiparáveis aos outros demais actantes da rede. É porque a rede cooperativa também conta com esses actantes que, por exemplo, o esforço de “invisibilização" das cooperações técnicas se realizam.

\section{Realidade negociada}

Como dito acima, as cooperações técnicas adquirem sua plena consumação a partir de estratégias que as tornem invisíveis. Entretanto, durante as execuções das performances não é incomum que elas sejam "chacoalhadas". Voltemos nossa atenção para a situação a seguir.

Eram dezesseis horas em Arraial d'Ajuda, distrito de Porto Seguro-BA, com dezessete mil habitantes. Quatro artistas da performance seguiram para o local que tinham escolhido para realizar suas ações, um campo gramado que os moradores da cidade chamam de "Faixa de Gaza". É um lugar que marca uma divisão entre a parte turística e a zona dos antigos moradores locais, que foram sendo deslocados para mais longe da orla marítima, através do processo de especulação imobiliária e correspondente gentrificação. A "Faixa de Gaza" é um espaço de alto fluxo de motocicletas e de pedestres durante todo o dia. Foi este o local que Sara Panamby, Laís
Guedes, Anibal Sandoval e Lucas Moreira escolheram para a realização de suas performances na segunda edição da Mostra MOLA.

Os quatro artistas estavam seminus, sendo que Lucas Moreira ficou completamente nu em dado momento, quando se lavava com água e em seguida passava terra sobre o corpo. Perto dele, Anibal vestia apenas um short preto e cavava um buraco na terra com ajuda de uma enxada. Em poucos minutos se instalou um pandemônio: um rapaz avançou em direção a Lucas dizendo "Vista a roupa, isto não é arte, é falta de respeito!” e, apontando para Anibal, que cavava o buraco, dizia “Aquilo é arte, isto é pouca vergonha”. Rose Boaretto e Bia Medeiros, curadoras do evento, começaram a conversar com ele logo chegou ao local uma viatura da polícia. Rose Boaretto, Fernanda Félix e eu nos voltamos para os policiais, tantando convencê-los a permitir o seguimento da performance. Fernanda havia apresentado o ofício que fora enviado para a Secretaria de Turismo e Cultura, os policias disseram que não havia sido informado e que receberam diversas reclamações dos moradores. Outras pessoas se aproximavam da gente e diziam que havia escolas por perto, que deveríamos fazer aquela ação à noite. As cooperações "invisíveis" da produção foram perturbadas. Fernanda se manteve conversando com os policiais e afirmando que tínhamos autorização da Prefeitura e que esta repassara o ofício para a Polícia Militar. Por fim, os policiais nos deram quinze minutos para sairmos de lá "Bem, ainda tínhamos quinze minutos", pensou Bia Medeiros, como me revelou depois. 
${ }^{5}$ Uma linha de atuação na performance art que trabalha com modificações corporais reversíveis e não reversíveis. A francesa Orlan, cujo corpo consta entre as obras de arte do Museu do Louvre, é a mais representativa entre os artistas desta modalidade de performance.
Aos poucos, a equipe de produção informava aos artistas o que se passava. Com a cooperação das produtoras, conversávamos com os artistas e conversávamos com pessoas do público sobre o que acontecia. Enquanto isso, outras pessoas juntavam-se ao redor de Sara Panamby, que realizava uma body modification $^{5}$ : tinha um tipo de extensor na boca para mantê-la sempre aberta, estava vestida com trapos e uma tira de ossos amarrados com um tecido cobria sua coluna. Fazia uma figura dantesca. Sua nudez estava ali, mas não era vista como fator de incômodo. Em determinado momento eu me aproximei do público que tinha se formado ao redor de Sara e uma mulher olhou para mim e disse: "Esse povo é engraçado, o cara lá ficou chateado com o garoto que estava nu, mas olha ele aqui vendo ela, isto é machismo! É nessas horas que a gente vê!"

Esse problema sobre a censura da nudez masculina e aceitação da nudez feminina não foi algo buscado pelos artistas na concepção de suas performances. Entretanto, essa questão política surgiu e foi claramente identificada por uma pessoa (talvez por outras que não tenham se manifestado) e era mesmo muito nítido. Em contexto machista, a nudez feminina é vista como censurável, mas pouco "agressiva"; já a nudez masculina é tida como muito agressiva e ofensiva à moral. Mas o aspecto mais relevante aqui é que os artistas, e particularmente Lucas Moreira, não pretendiam despertar aquele efeito de transgressão moral. Esse tipo de imprevisto, como outros tantos, ocorre porque o limite pouco definido entre arte e não-arte que a performance traz permite interações muito surpreendentes.
Perguntei à mulher (que não parecia fazer relação entre mim e o grupo dos criadores do evento) por que se mantinha ali, acompanhando a performance de Sara. Ela respondeu: “É interessante, né não?! A gente fica com medo, ela está fazendo medo, as crianças acham que é um monstro, mas isso atrai”. Nesse caso, as entidades que operavam na ação performática pareciam não estabilizar o estatuto de arte, e as "cooperações técnicas" tinham sido completamente desestabilizadas. Ainda assim, as pessoas se mantiveram por horas e, mesmo tendo sido informadas que se tratava de um festival de arte, a estranheza que se indica na questão "O que está ocorrendo aqui?" não se arrefecia: "É mesmo arte?".

Figuras 2 e 3. PANAMBY, Sara; MOREIRA, Lucas Sem título. Porto Seguro-BA.

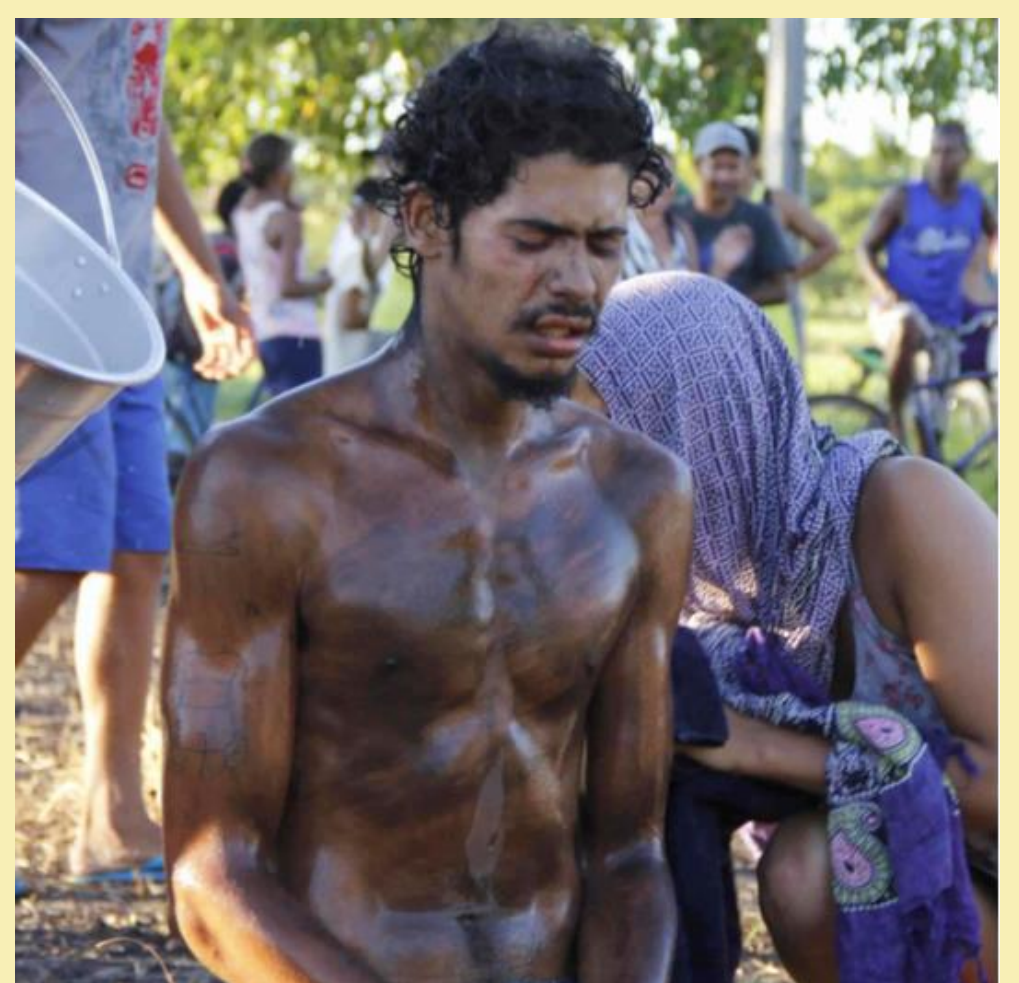


http://g1.globo.com/distritofederal/noticia/artista-detido-pela-policiadurante-performance-de-nu-artisticovolta-ao-df.ghtml

https://www.cartacapital.com.br/sociedad e/museu-de-sp-e-acusado-de-pedofilia-erebate-performance-nao-tem-conteudoerotico

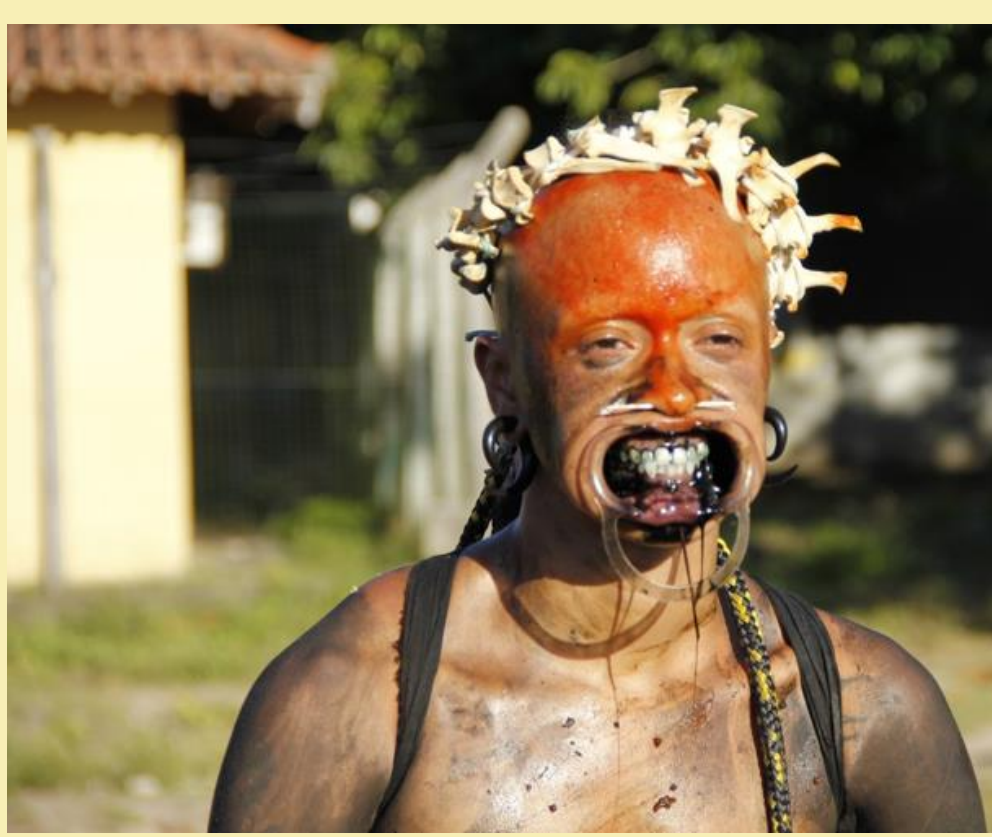

Fotografia:Pâmela Guimarães. Fonte: Acervo MOLA

Antes de conclusões claras, estes acontecimentos apontam para algumas formulações que apelam para futuras análises. A instabilidade da performance, ou seja, sua não inscrição prévia em um formato definido de espetáculo com seu correspondente horizonte pré-delineado de expectativas é que pode levá-la a se tornar, por exemplo, "caso de polícia" ou uma "heresia". E a rua como espaço para as interações performáticas geralmente se torna uma aliada nesse processo de "negociação de realidades"; no sentido de reforçar essa instabilidade, como foi visto acima. Importante registrar, porém, que esse tipo de reação de animosidade não é um efeito que ocorra em toda performance, como pode ser observado em outros registros da pesquisa. (FÉLIX MARTINS, Daniela, 2017) Entretanto, alguns acontecimentos recentes de performances que trabalharam com a nudez do corpo masculino, parecem indicar os interditos da sociedade brasileira, colocando a arte da performance na mira de uma perseguição moral.

Refiro-me ao caso do artista paraense Maikon Kempinski que foi preso durante a performance "DNA de Dan" (2017) realizada na praça do Museu da República em Brasília ${ }^{6}$, e a performance "La Bête" (2017) do artista Wagner Schwartz, realizada no Museu de Arte Moderna de São Paulo e que sofreu uma série de ofensas nas redes sociais ${ }^{7}$. Desse modo, o que parece está em jogo nesses casos é sempre um problema de composição, ou mesmo uma disputa em torno de valores

Não se trata mais de saber se o que vemos é bonito ou feio, se o artista tem ou não talento, se pinta bem ou não - mas de saber se o que vemos é arte ou não, se seu autor é artista ou não, e acessoriamente quais são os critérios pertinentes em matéria de arte. A questão da beleza dá lugar à questão da autenticidade artística, que não se reduz mais a uma querela de atribuição (de qual mão é esta obra?), mas se torna, em âmbito geral, uma discussão sobre as fronteiras da arte ou mesmo sobre os valores que devemos defender quando a obra põe em jogo a transgressão. (HEINICH, 2011 p.89)

\section{No chá das cinco}

Durante a segunda etapa do trabalho de campo, elementos importantes na compreensão a que eu chegara sobre a performance art estavam ausentes dessa arte em Londres, onde a performance 
tinha espaços institucionais, os eventos eram amplamente divulgados por veículos de grande circulação como Time out, Evening Standart e The Guardian, além das redes sociais na internet.

Figura 4: Banner na Tate Modern. Londres. Fotografia: Daniela Félix Martins, 2015.

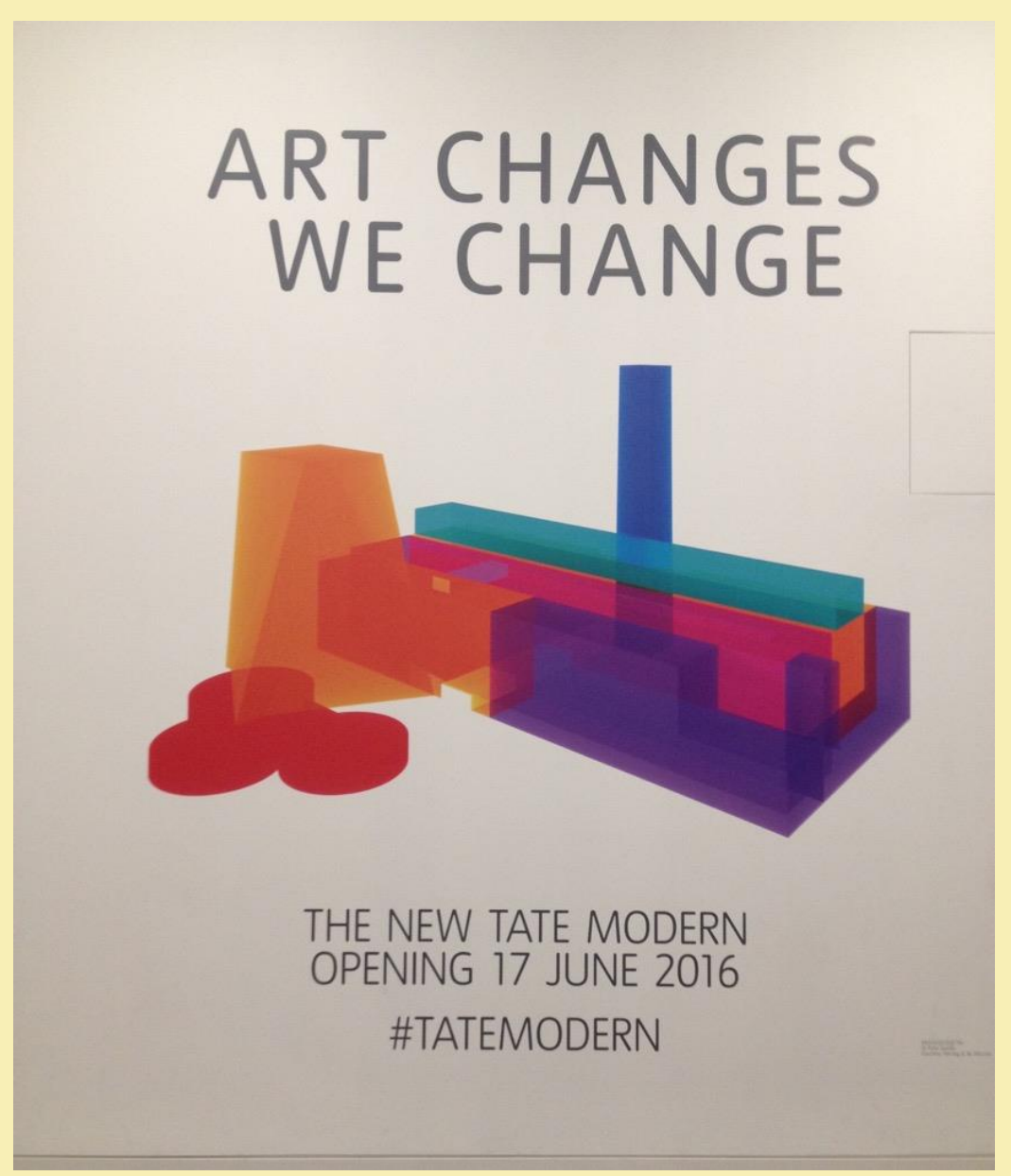

Na Tate Modern havia duas exposições com artistas de performance, Joseph Beuys na exposição "Artist rooms" e Rebeca Horn numa exposição coletiva chamada "Making Traces". Nestas ocasiões, o que estava em exposição eram fotografias, vídeos e, no caso de Rebeca Horn, também objetos e roupas utilizados nas performances realizadas. Nesse mesmo museu havia o informe da construção de um novo pavilhão para abrigar esse tipo de arte inaugurado em junho de 2016. Na Curve Art Gallery no Barbican Centre havia a exposição "The Forever Loop" do artista inglês Eddie Peake. Tratava-se de uma exposição comissionada pela própria galeria através do financiamento público do Arts Council English (fundo governamental dedicado ao financiamento e promoção das artes no Reino Unido) e da Henry Moore Foundation (fundação criada pelo artista Henry Moore com o objetivo de formar público e promover realizações nas artes visuais, além de divulgar seus próprios trabalhos). Eddie Peake combinava diversos tipos de arte em sua exposição: instalação, escultura, video, pintura, dança performance. Assim, ao atravessar a galeria o visitante era surpreendido por patinadores deslizando de um lado para outro, dançarinas e dançarinos nus ou semi-nus ocupando partes da instalação. A performance no Reino Unido foi adquirindo o status de arte estabelecida e a condição de arte-vida (live art) um aspecto fundamental nestes tipos de trabalho. $\mathrm{Na}$ entrada da galeria os funcionários informavam a proibição do registro em vídeo e foto da exposição pelos visitantes. Essa era uma advertência sempre presente em outros eventos de que participei em Londres, como a

Dossiê Práticas e Políticas Culturais: Paradoxos e diálogos com a tecnologia 
Define-se como performance duracional, àquelas em que o tempo constitui a materialidade do trabalho.

\section{Daniela Félix Carvalho Martins}

"performance duracional"8 $D R A W N$, de Stuart Brisley, na David Robert Art Foundation (DRAF), no bairro de Camden Town.

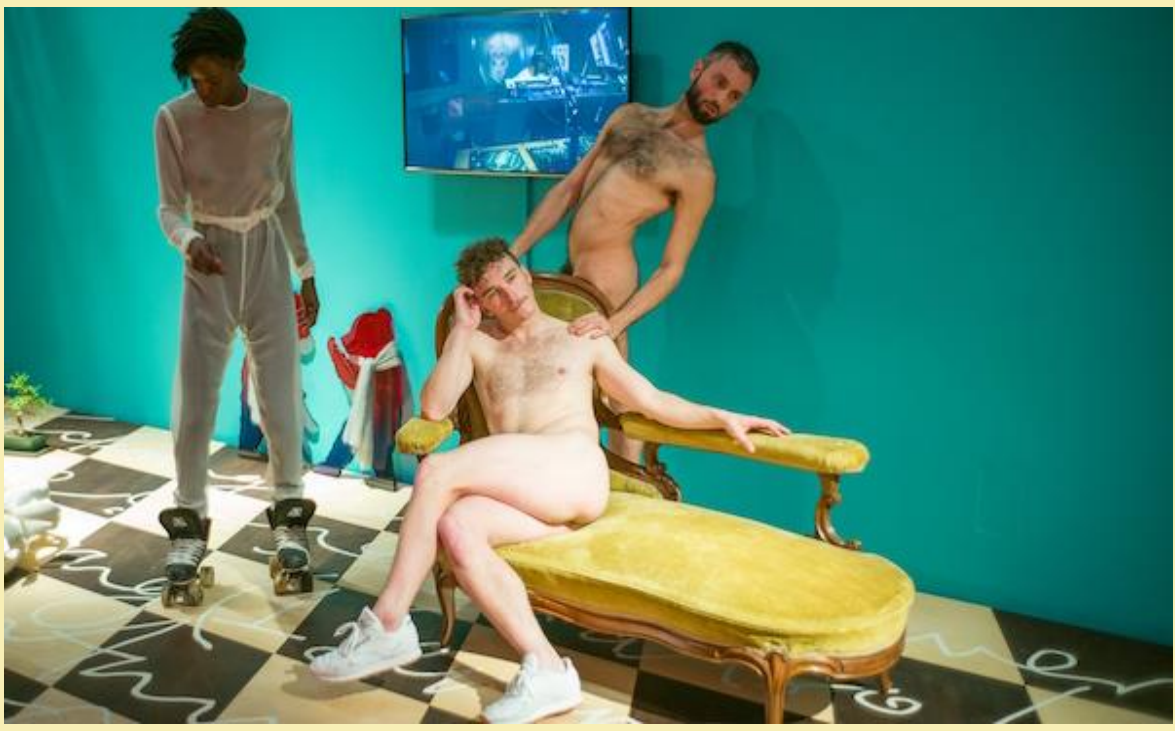

Figura 5: PEAK, Eddie. The Forever Loop. Londres. Fotografia: Graeme Robertson. Fonte: Barbican, 2015

A DRAF é um antigo galpão adaptado como galeria de arte. No segundo andar da galeria havia um sala ocupada por uma exposição com catálogos e vídeos de outros trabalhos realizados pelo artista. Antes de ingressar na sala principal, onde estava acontecendo a performance, os visitantes deveriam depositar seus celulares e câmeras numa caixa; os aparelhos eram identificados por um número para serem retirados na saída. Essa performance teve duração de quatro dias, realizando-se durante $\mathrm{o}$ horário normal de funcionamento do espaço (12h às $18 \mathrm{~h}$ ). Na sala havia dois longos bancos de madeira juntos à parede, cada um com capacidade para dez pessoas sentarem. No primeiro dia, o público foi bastante reduzido, as pessoas puderam ser acomodadas no espaço dos bancos. Ao meu lado, uma mulher traçava desenhos em um caderno, reproduzindo algumas das situações que se desenrolavam na performance; havia apenas uma fotógrafa que registrava intensamente o trabalho de Brisley. No terceiro dia, constatei um aumento considerável do público. A fotógrafa passou a indicar lugares para a acomodação do público e, constantemente, pedia silêncio aos que chegavam. Havia muitas pessoas em pé e observei que ela as orientava a situar-se nos "ângulos mortos" na sala, o que permitia o registros da ação performática sem muita interferência de imagens do público.

A performance de Stuart Brisley, artista octagenário, conhecido como o "avô" da performance no Reino Unido, pode ser descrita como um trabalho que busca os limites físicos do corpo. Durante os quatro dias ele movimentava incessantemente uma série de objetos dispostos no espaço, com uma corda amarrada a eles e ao corpo de Brisley: cadeiras, mesas, espelhos, praticáveis, papéis, roupas etc. eram assim deslocadas, oferecendo resistência e exigindo esforço dele, em maior ou menor grau a depender de como se emaranhavam e amontoavam ao serem puxados pelo corpo do artista. O release disponível no site da DRAF (http://davidrobertsartfoundation.com/projects/draf-studio-_-stuartbrisley/) informava que a performance faz referência ao mito de Procusto. Filho de Poseidon, era ferreiro de ofício e tinha o hábito de convidar peregrinos para passar a noite em suas duas camas de ferro; com seu martelo, Procusto ajustava seus convidados ao espaço da 
cama, cortando partes de seus corpos se assim fosse necessário para o ajuste. Como ele sempre encolhia mais e mais esse espaço destinado aos convidados, ninguém jamais cabia exatamente nas suas camas.

No terceiro dia a sala estava repleta de pessoas. Brisley continuava a mover os objetos de modo desordenado, amarrando-os e puxando-os com a corda que os atava a ele. Algumas vezes uma cadeira enganchava num praticável e Brisley precisava empregar uma força maior; nestes momentos os objetos se chocavam com força e espalhavam-se pelo espaço fazendo a audiência se mover, encolhendo as pernas para evitar a coalizão com alguma cadeira que despencasse do alto de duas mesas; às vezes, alguns precisavam mudar de lugar para esquivar os objetos. Durante um longo momento resolvi permanecer em pé, tentando evitar a "cama de ferro" de Brisley. Apesar de sua idade avançada, ele se movia com agilidade e com ele os objetos eram enérgicamente arrastados; escutavam-se os sons altos de choques desses objetos entre si, com as paredes ou o chão de cimento; em vários momentos, também era audível a respiração ofegante do artista, que com isso comunicava sua exaustão. A cada dia o espaço ia se modificando, cada vez mais se fazendo caótico.

Figura 6: BRISLEY, Stuart. DRAWN. Londres. Fotografia: Maya Balcioglu. Fonte: David Robert Foundation

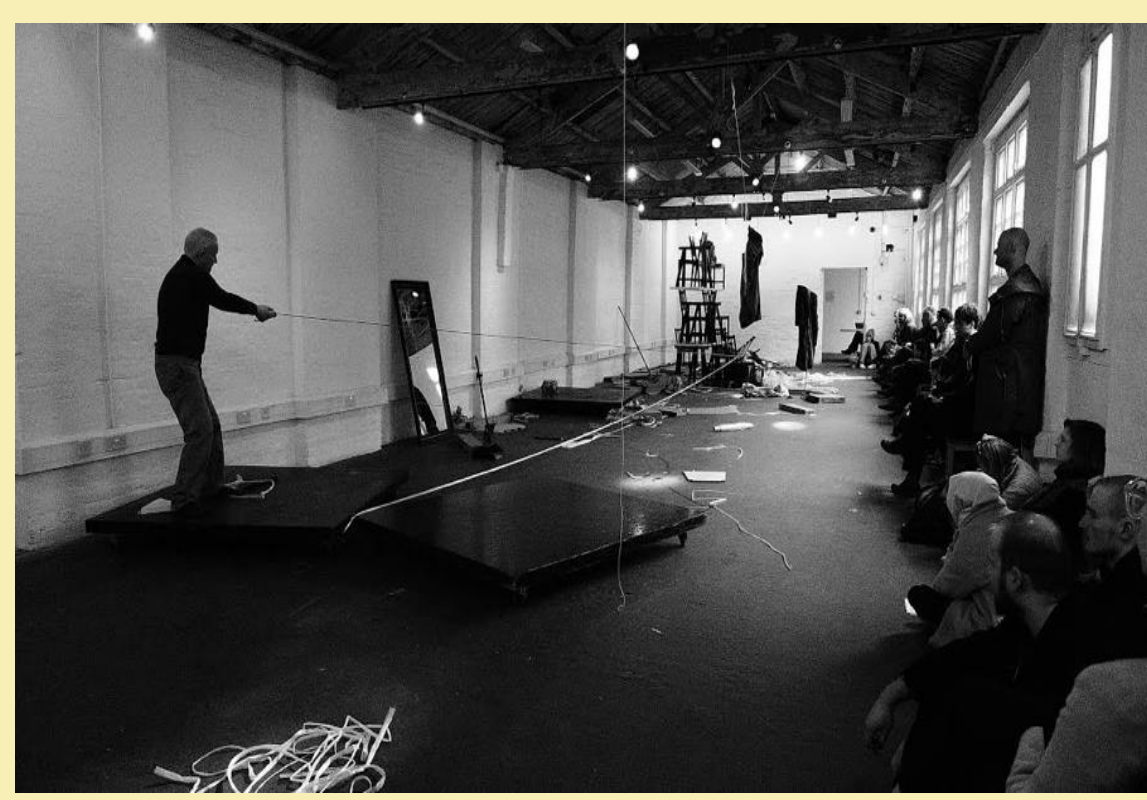

Com o desenvolvimento do campo da pesquisa, essas restrições a registros das performances por parte do público, e o controle na produção desses registros através de fotógrafos autorizados, indicavam o acolhimento dessa forma artística no mundo institucional da arte. Isto é, os registros de performance são obras para o mercado de arte, ao menos em potencial. Um dos temas mais relevantes para curadores, galerias, museus e colecionadores sobre esse tipo de arte é exatamente o de como realizar exposições e aquisições de performance. Um exemplo dessa preocupação pode ser visto no grupo de pesquisa "Collecting the Performative", da Tate Modern:

Como a capacidade de existir independentemente do artista é considerado um pré-requisito fundamental para uma obra de arte a ser colecionável e vendida, essa falta 
de autonomia exclui trabalhos de performance do mercado ou das coleções. Trabalhos que agora estão entrando em coleções foram criados de forma a deixar de ser dependentes do artista como intérprete, ou consistem em trabalhos mais antigos onde o artista pôde, uma vez realizado o trabalho, ser reformulado para oferecer uma performance alternativa Apesar dos esforços para reformular a performance como independente do artista que os fez, na prática, as relações permanentes de artistas com suas obras é mais forte do que nos demais gêneros tradicionais. $\mathrm{O}$ processo de ensaio e direção para realizar a visão específica do artista de uma performance realizada fora do âmbito tradicional do museu, e quando a performance é re-executada ou exibida o artista tem que voltar a envolver-se com a instituição. (TATE MODERN, 2012 [Tradução nossa])

Essa aceitação da performance em espaços institucionais no Reino Unido é resultante de um desenvolvimento de políticas públicas que tem seu auge na década de 90, como demonstrou a análise documental realizada na LADA. No ano de 1971 ocorreu a primeira exposição de performance com subsídio público, Art and Economics da APG (Artist Placement Group), que teve lugar na Hayward Gallery porém, o subsídio veio a ser retirado, sob alegação de que aquilo que APG fazia não era arte. O Arts Council(fundo governamental dedicado ao financiamento e promoção das artes no Reino Unido) afirmou que o grupo estava "mais preocupado com engenharia social que com arte séria" ("more concerned with social engineering than with straight art”). Segundo Klein (2012), o fundo público deparava-se com uma diversidadade de nomenclaturas utilizadas pelos praticantes deste tipo de arte no período - body art, happenings, actions, conceptual art, experimental dance e experimental ou fringe theatre - o que formava uma confusão implicou em perda dos parâmetros que o Arts Council necessitava para lidar com aquela exposição em 1971. Klein também afirma que a suspeita dos financiadores em relação a essas denominações polivalentes foi acompanhada de um anátema que os praticantes da live art lançavam sobre qualquer ato que sugerisse institucionalização. Apenas em 1985, como registra La Frenais (1986), é que o Arts Council veio a dotar recursos para artistas da performance, no formato ad hoc, e a iniciar a promoção dessa arte através de financiamento público.

$\mathrm{Na}$ década de 1990 ocorreu um desdobramento desse fenômeno com alterações das quais a primeira delas é o recolhimento da variedade de denominações de formas artísticas (que perturbara o Arts Council) pelo termo live art. Adrian Heathfield, curador, crítico de arte e um dos principais responsáveis pela popularização desse termo, sugere que live art é uma definição que propõe um impulso da arte e cultura contemporâneas na direção do imediato, imersivo e interativo: "a shift to the live" (HEATHFIELD, 2004, p. 7). O termo passará a ser largamente adotado, inclusive pelo Arts Council, como indica o relatório de Lois Keidan destinado a esse Conselho, "Strategy: Discussion Document on Live Art" (1991), cujo objetivo era, exatamente, mapear práticas e formas de manutenção para a live art. O trabalho de Keidan é marcado pelo esforço de distinguir a prática de live art, que

Dossiê Práticas e Políticas Culturais: Paradoxos e diálogos com a tecnologia

Arquivos do CMD, Volume 5, N.1. Jan/Jul 2017 
"atravessa e subverte os limites da forma de arte tradicional" ("cuts across and subverts traditional art form boundaries"), de outras práticas artísticas.

Uma das recomendações do relatório de Lois Keidan foi a de que se construíssem organismos institucionais que possibilitassem a consolidação e a plena sustentabilidade desta forma artística, pois, apesar do interesse crescente pela performance, várias dificuldades permaneciam para essa arte. Por exemplo, além dos obstáculos enfrentados pelos artistas para realização de suas performances, Keidan aponta a dificuldade de construção de uma rede de trabalho que permita o desenvolvimento e consolidação desta forma artística

Um importante resultado desse empenho em apontar os problemas pela live art e, ao mesmo tempo, reivindicar soluções para eles, é a fundação da LADA, em 1997 - com Lois Keidan como diretora, cargo em que permanece até hoje. Em outras palvras, a fundação da LADA é um marco no trabalho de institucionalização da performance. E, além disso, liga-se ao momento em que a “indústria criativa" é incorporada às políticas de Estado:

Fundada no fim do século XX, a LADA coincidiu com a vitória do New Labour que destronou os conservadores em 1997. A postura neoliberal do New Labour é escrita através de sua relação com a atividade artística, encapsulada na sua ressignificação das artes como "indústrias criativas 'que geram' economias criativas". 'O empreendedorismo e a mercantilização da produção artística estão no cerne da visão das "indústrias criativas" do New Labour. A publicação governamental "Creative Industries Mapping Document" (1998) definiu as indústrias criativas como "aquelas atividades que têm sua origem na criatividade, habilidade e talento individuais e que têm potencial de riqueza e criação de empregos através da geração e exploração da propriedade intelectual. (HEDDON \& KLEIN, 2012, p. 28)

Figura 7: The White Building -LADA. Londres. Fotografia: Daniela Félix Martins, 2015

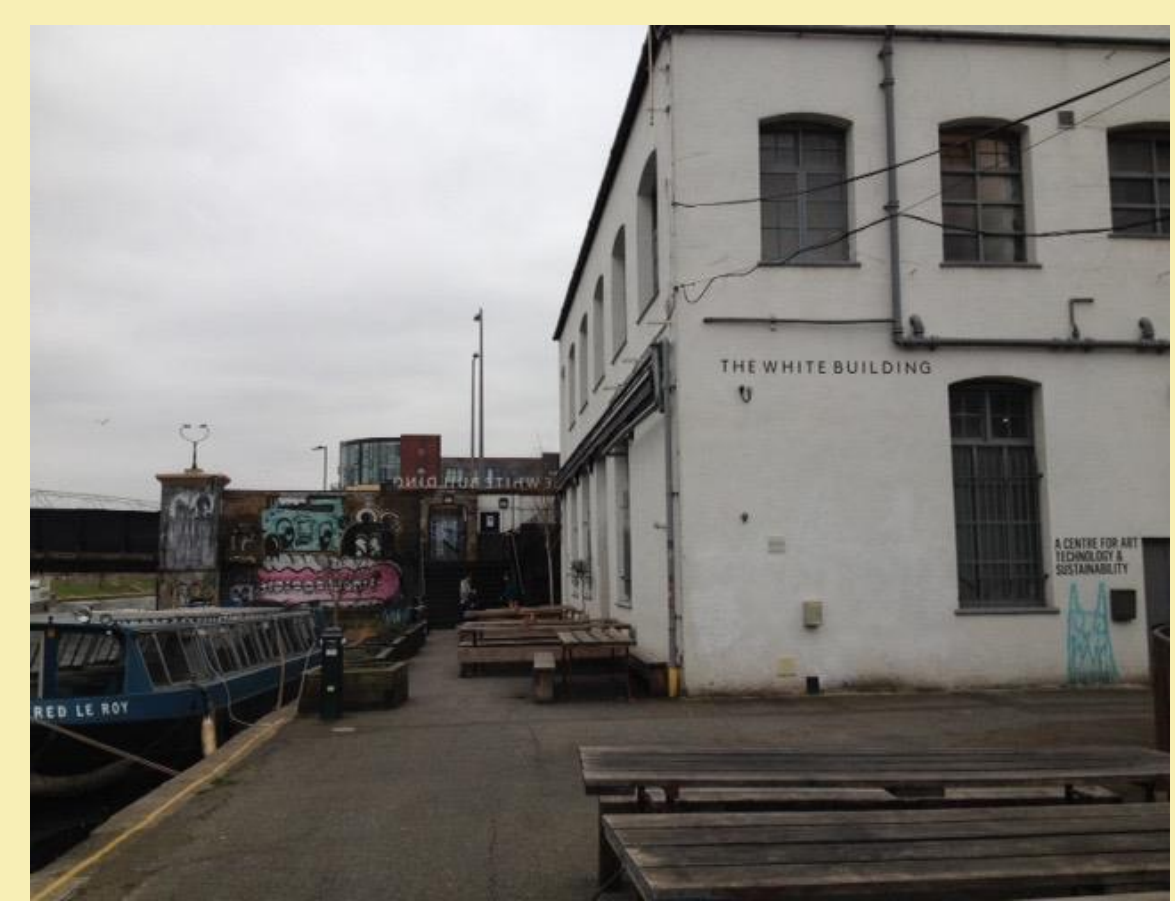

Esses acontecimentos produziram uma estabilização dessa forma artística e o fim das controvérsias sobre seu estatuto artístico no Reino Unido, à medida que ela passou a "habitar uma categoria própria", como escreve Klein neste outro trecho: "Performance art, ou Live art como ficou sendo mais conhecida, era tanto do presente

Dossiê Práticas e Políticas Culturais: Paradoxos e diálogos com a tecnologia

Arquivos do CMD, Volume 5, N.1. Jan/Jul 2017 
como parte da história, efêmera e capaz de ser exibida, desafiando a categorização e ainda habitando uma categoria própria” (Idem, 2012, p. 23 [Tradução nossa]).

Ocorre que, ao adentrar o museu e outros espaços da arte convencional, a performance artllive art parece levar consigo sua ambiguidade constitutiva - o fluxo de instabilidades/estabilidades, fazendo hesitar a certeza desses espaços legitimados que a acolhem e, com isso, contaminando as artes com as quais passou a co-habitar. Em suma, pode-se dizer que a acolhida da live art no museu e congêneres, em vez de fazer cessar a ambiguidade da performance, incidentalmente a instila no estatuto da arte historicamente institucionalizada, fazendo oscilar a própria categoria arte, que passa a ser incessantemente questionada. Além disso, a ambiguidade que a performance art faz habitar nesses setores institucionais produziu e continua a produzir alterações - em museus, galerias, no mercado de arte e coleções privadas - relativas ao problema de como lidar com a reprodução e/ou a compra e venda das ações performáticas. Isto é, constatamos que o fluxo de instabilidade migrou para as controvérsias da acolhida da performance nessas instâcias convencionais do mundo da arte.

Em outras palavras, algumas performances adquiridas por instituições são executadas pelo museu, isto é, a ação performática é levada a cabo por integrantes dessas instituições. No que diz respeito ao mercado de arte, em termos de como lidar com essa instabilidade, novos actantes são convidados a participar, nesse caso os regimes jurídicos se tornaram fundamentais para o processo de venda no sentido de tentar definir questões como: O que é a obra em questão? Qual o papel do colecionador? Quem é o artista? Quais as condições para sua exibição e revenda? A acolhida da performance pelos museus tem como consequência a atração dos interesses do mercado de arte. Nesse processo a tradução operada se dá entre "valores estéticos" e "valores econômicos", isto é, a produção de uma rede complexa de legitimações e circulações de valores em torno da produção artística.

Um bom exemplo é o caso da aquisição da performance "Good Feelings in Good Times" (2004), do artista eslovaco Roman Ondák, originalmente comissionada pela Frieze Art Fair, principal Feira de Arte de Londres, e posteriormente adquirida pela Tate Modern. Ao adquirir "a obra”, essa instituição adquiriu de fato as instruções para sua realização. Assim, a "ativação” da obra de Ondák é delegada à Tate, tornando-se com isso independente da presença do artista ou mesmo de seus assistentes. As instruções de "Good Feelings in Good Times" estabelecem parâmetros dentro dos quais o trabalho deve ser realizado, mas a instituição compradora tem certo espaço interpretativo; por exemplo, pode decidir em que lugar ativála e quem incluir nessa ativação. No site da Tate Modern (http://www.tate.org.uk/art/artworks/ondak-good-feelings-in-goodtimes-t11940/text- summary), "Good Feelings in Good Times" é descrita como uma fila criada artificialmente. Essa fila pode ser formada no museu ou também pode ser adaptada para outros espaços, mas deve sempre ser executada em conjunto com outro acontecimento artístico, ou seja, deve estar inserida nesse espaço de 
outra/s exposição/ões. Pode ser formada tanto em um ponto onde faria sentido a existência de uma fila ou - para um aumento em suas propiciações - pode também ser formada em pontos ligeiramente inesperados, mas não totalmente despropositados. A instrução de "Good Feelins in Good Times" estabelece que nas "reperformances" no interior do museu deve-se garantir um mínimo de sete e um máximo de doze pessoas; ao ar livre, deve haver um máximo de quinze pessoas.

Quanto aos participantes da fila, podem ser voluntários ou atores contratados pelo museu, sem restrições quanto a idade ou sexo nem obrigação de usar roupas específicas, mas devem portar objetos pessoais (seus reais ou supostos pertences) e permanecer na fila como se estivessem esperando por algo a acontecer; se questionados, não estão autorizados a divulgar nada sobre a performance. A fila deve ser repetida diversas vezes durante o dia, de acordo com cronograma acordado entre o artista e o museu, que contempla certa margem de flexibilidade; normalmente, são períodos de quarenta minutos de execução com intervalos de vinte minutos entre sessões para que os participantes descansem, sem serem vistos pelo público em geral. Assim, a fila deve se formar e dissolver e formar novamente várias vezes no dia, com os participantes comportando-se discretamente e tão naturalmente quanto possível. Segue trecho do texto do site da Tate sobre a obra:

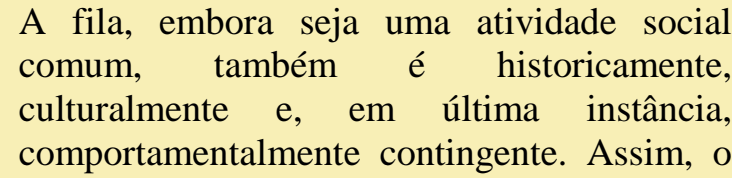

Dossiê Práticas e Políticas Culturais: Paradoxos e diálogos com a tecnologia

Arquivos do CMD, Volume 5, N.1. Jan/Jul 2017 trabalho pode adquirir diferentes conotações dependendo do espaço e tempo de sua execução. Inspirado pelas próprias lembranças do artista das longas filas formadas fora das lojas de supermercado na sua Eslováquia nativa na era comunista (Ondák citado por Andrews), o trabalho provavelmente assumiu um significado diferente na Frieze Art Fair, onde a localização de Londres e sua atmosfera onde a localização de Londres e sua atmosfera
agitada podem ter evocado o hábito mais quintessencialmente britânico de fazer fila e o sofrimento diário dos viajantes da cidade, devido a longas esperas. Re-performada na Tate Modern, a fila pode ser entendida como chamando a atenção para as várias funções da instituição, ou simplesmente dando ao artista uma plataforma para explorar algumas questões maiores relacionadas com filas que lhe interessam. (TATE MODERN, 2003 [Tradução nossa])

Figura 8: ONDÁK, ROMAN. Good Feelings in Good Times. Londres. Fonte: Tate Modern, 2003

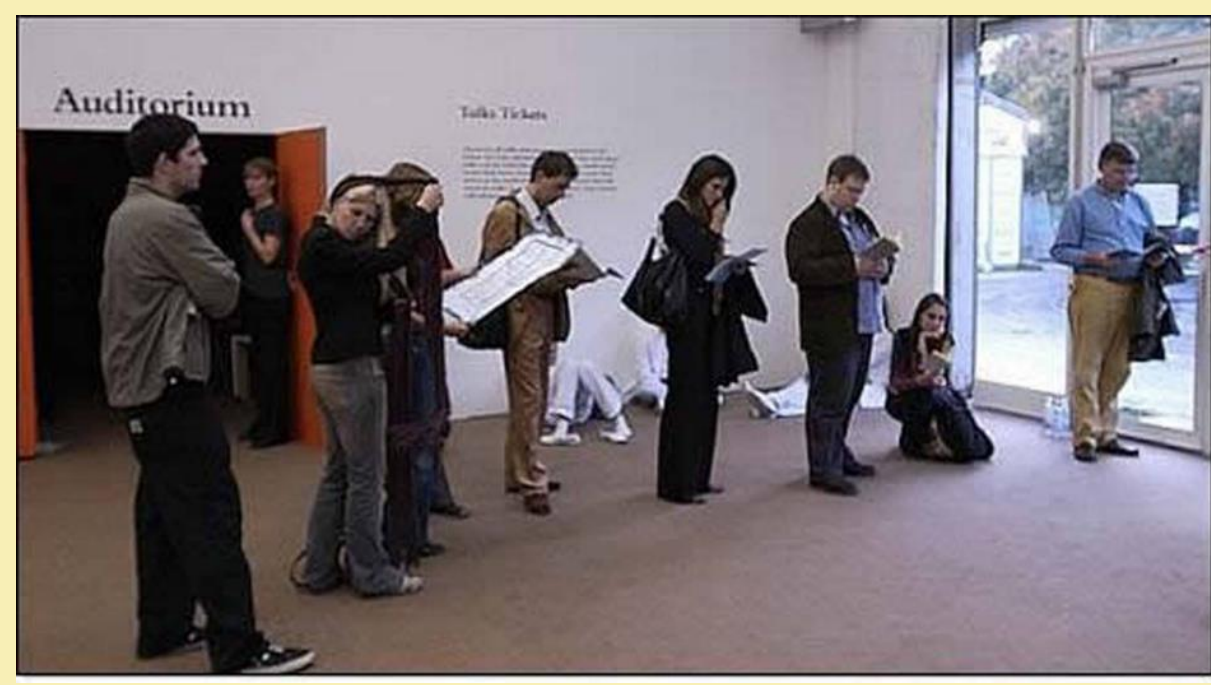

Importante notar, ocorreu uma inovação no estatuto da Tate Modern que, ao adquirir "Good feelings in Good Times", passa a ser 
o agente "ativador" da obra. Isto é, houve com essa transação uma mudança no aspecto preservacionista típico da musealização, cujo procedimento normal consiste na retirada de um determinado objeto de um fluxo, através de uma seleção criteriosa em que ele receberá um novo status, de "objeto museológico" e/ou "objeto artístico". Lançando-se no fluxo da performance, porém, o Museu torna-se mais um actante na criação performática - sendo que sua participação terá papel decisivo no sucesso ou fracasso da obra. Nesse caso, "preservar" não significa extrair uma obra de determinado lugar de circulação e alocá-la no Museu, ou seja, a Tate não atua como um intermediário, mas sim como um mediador fundamental - que, no processo de transladar a performance, ao mesmo tempo se transforma. Assim, a questão que se torna importante não é a da autonomia da obra em relação ao artista; é a da fidelidade aos parâmetros contratualmente estabelecidos, para garantia da integridade da obra.

Do ponto de vista legal, afora a dificuldade frequente em definir o que é a obra de performance, também é difícil estabelecer de forma clara quais termos estão subjacentes à venda e, portanto, se há e quais são as obrigações legais do colecionador com o artista em relação a seu trabalho. Tal como na venda de "Good Feelings in Good Times", do artista eslovaco Roman Ondák, é comum que o único registro da venda seja a fatura, ficando a construção dos termos práticos de um contrato a cargo do diálogo entre as partes. Assim, se regimes jurídicos permitem que obras "ao vivo" sejam "traduzidas" em instruções legalmente autorizadas, o "regime" de certificação, contudo, deixa em aberto a pergunta de como o artista poderá controlar a futura interpretação da obra.

O contrato escrito é um instrumento que fornece aos artistas mecanismos mais eficazes para o controle da exposição e interpretação da ação performática após sua venda, através da imposição de obrigações legalmente aplicáveis ao colecionador ou ao museu - e só recentemente vem sendo mais utilizado nas transações comerciais de performance delegada.

O artista Tino Sehgal, por exemplo, vende não apenas um conjunto de instruções que ele comunica verbal e pessoalmente, mas também um "corpo inteiro de compreensão" em torno da performance objeto da venda, de modo a fazer que o novo proprietário partilhe dessa compreensão e venha a tornar-se capaz de ativá-la corretamente. Sehgal não permite qualquer gravação ou documentação da obra e é conhecido atualmente como um artista que leva a transmissão oral da venda de performance ao limite. Suas obras são vendidas, muitas vezes, sob a condição expressa de serem executadas somente por artistas que ele escolha pessoalmente e, além disso, de que ele também possa manter os direitos de exibição da performance comercializada. As "Constructed Situations" criadas por Sehgal são vendidas através de contratos verbais. A transação é efetuada diretamente pelo artista a um comprador, geralmente um representante do museu, diante de um advogado, um notário nomeado por ele e testemunhas. As regras de propriedade em torno da venda das "Constructed Situations" de Sehgal têm pelo menos seis condições básicas: 
- O trabalho deve ser ativado somente por Sehgal ou por um assistente autorizado por ele;

- O trabalho deve ser mostrado por um período mínimo, previamente acordado;

— Os "intérpretes" (outros performers que não o próprio artista) devem receber um pagamento mínimo previamente acordado;

- O proprietário deve tomar medidas para evitar qualquer filmagem ou fotografia da obra;

- Caso o proprietário deseje emprestar a obra, pode fazê-lo apenas com o consentimento prévio de Sehgal;

— Em caso de revenda, deverão ser observados os mesmos termos do mesmo contrato oral da primeira venda.

Tino Sehgal parece querer (e conseguir) deixar claro que possuir uma obra de performance é também lançar-se em seu processo de criação e execução - sob o pressuposto de ela jamais está pronta de uma vez por todas, mas sempre irá demandar "a mão" de um outro, como, por exemplo numa corrida com bastão, em que a tomada sucessiva do bastão por outros é exigível para o prosseguimento da corrida. Sendo que, no caso da performance, a "pista de corrida" análoga não é nunca como linear e estreita, mas pode ser comparada a uma grande clareira que se estende na medida das retomadas, que aliás são feitas por participantes que podem correr em diversas direções.
Figura 9: SEHGAL, Tino. The Kiss. Nova York. Fonte: Guggenheim Museum, 2010

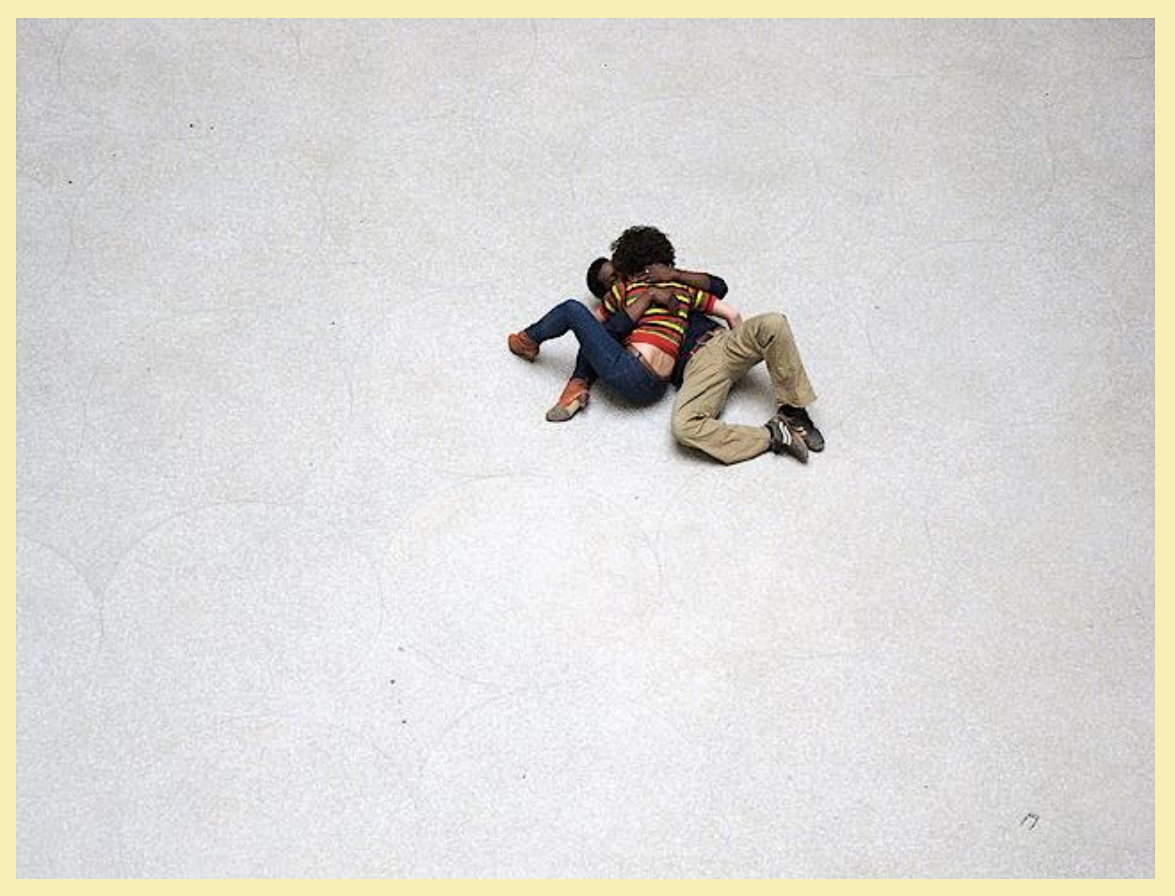

\section{Considerações finais}

Por fim, é preciso dizer que essa apresentação da performance tem um caráter panorâmico, em certo sentido: é que era necessário oferecer uma vista geral dessa arte que aparece como nova. Todavia, há muitas direções indicadas neste texto que convidam a uma dedicação exclusiva, com um aprofundamento de sua investigação. 
Assim por exemplo, os problemas do direito envolvendo a performance; ou uma pesquisa específica da percepção dos públicos participantes da performance em diversas circustâncias espáciotemporais; ou sobre o trajeto do artista entre a concepção e a realização (sempre coletiva) da performance; e há também uma lacuna de investigação sobre o papel do Estado, pela elaboração de políticas públicas, para a permanência da performance; ou ainda uma pesquisa específica dos instrumentos oferecidos pela sociologia da arte para pensar essa forma artística; finalmente, um estudo dos impactos dos desenvolvimentos teóricos recentes que, da sociologia à antropologia, pensam sobre as coisas que povoam o mundo, distanciando-as de seu estatuto filosófico anterior que considerava como seres inertes para um sujeito humano ativo.

Sobre esta última sugestão de desdobramento: como se sabe hoje, a partir de Bruno Latour, Alfred Gell, Tim Ingold, Isabelle Stangers e, mais recuadamente no tempo, com Maurice MerleauPonty e Étienne Souriau, as coisas interagem todo o tempo conosco, e nelas se incluem, naturalmente, as coisas que conforman os acontecimentos artísticos. Talvez não coubesse aqui elencar todos os desenvolvimentos possíveis a partir dos diversos pensadores direta ou indiretamente ligados ao âmbito do estudo das artes, mesmo que eu fosse capaz de fazê-lo. O que buscou-se elaborar nesse artigo foi assim, uma visão panorâmica a partir de algumas controvérsias no mundo da arte da performance.

\section{Referências}

BECKER, Howard. Art as a coletive action. American Sociological Review, Washington, Vol. 39, No. 6, 1974, pp. 767-776

Uma teoria da ação coletiva. Rio de Janeiro: Zahar, 1977. Los mundos del arte: sociología del trabajo artístico. Bernal: Universidad Nacional de Quilmes Editorial, 2008.

FÉLIX MARTINS, Daniela. A novidade da Performance Art: Exploraçõe em sociologia associativa. 198 f., il. Tese (Doutorado em Ciências Sociais) - Universidade Federal da Bahia, 2017

HEATHFIELD, Adrian (org.) Live: Art and Performance. London: Tate Publishing and Routledge, 2004

HEDDON \& KLEIN. Histories \& Practices of Live Art. London: PALGRAVE MACIMILLAN, 2012 HEINICH, N. The Glory of Van Gogh: an anthropology of admiration. Princeton : Princeton University Press, 1996

A sociologia da arte. Bauru-SP: EDUSC, 2001 . As reconfigurações do estatuto de artista na época moderna e contemporânea. Revista Porto Arte: Porto Alegre, v.13, n.22, 2005 - A arte contemporânea exposta às rejeições: contribuição uma sociologia dos valores. Observatório No 12, São Paulo: Itaú Cultural, 2011

Práticas da arte contemporânea: uma abordagem pragmática a um novo paradigma artístico. Sociologia\&Antropologia, Rio de Janeiro Vol. 04, No 2, 2014, pp. 273-390.

KEIDAN, L. National Arts and Media Strategy: Dicussion on Live Art. London: The Arts Council of Great Britain, 1991.

LA FRENAIS, R. News: Backstairs Revolution in Performance Art Performance Magazine 40 (março/abril), 1986, pp. 40-41

LATOUR, Bruno. On technical mediation - philosophy, sociology, genealogy. Common Knowledge, v. 3, n. 2, 1994, p. 29-64

Como falar do corpo? A dimensão normativa dos estudos sobre a ciência. In: NUNES, J. A.; ROQUE, R. (Org.). Objetos impuros: 
experiências em estudos sociais da ciência. Porto: Afrontamento, 2007. p. $40-61$

O que é iconoclash? Ou, há um mundo além das guerras de imagem?Horiz. antropol., Porto Alegre , v. 14, n. 29, 2008

Reflections on Etienne Souriau's Les Modes d'existence. In: HARMAN; BRYANT; SRNICEK. The Speculative Turn Continental Materialism and Realism, Melbourne, 2011, pp. 304-333.

Reagregando o social: uma introdução à teoria Ator-Rede. Salvador: EDUFBA, 2012.

Investigacion sobre los modos de existencia:uma antropologia dos modernos. Buenos Aires: Paidos, 2013. $\overline{5, \text { n. } 10,2015}$

Uma sociologia sem objeto? Revista-Valise, Porto Alegre, v.

MCCLEAN, Daniel. Collecting Live Art: Performance and the law. In: Calonje, Teresa. Collecting Live Art. London: Koenig Books, 2014

MCMILLAN, M. Cultural Grouding: Live Art and Cultural Diversity: Action Research Project: A report for the Visual Arts Department of the . Lond for: Arts Council of Great Britain, 1990

PEIXOTO, José Mário. Breve histórico da performance art no Brasil e no mundo. Revista Ohun, Salvador, Ano 4, No 4, 2008, pp. 1-32.

SANSI-ROCCA, Roger. Art, anthropology and the gift. London: Bloomsbury, 2015.

STENGER, Isabelle. The cosmopolitical proposal. In: LATOUR, B. and WEIBEL, P (eds) Making Things Public: Atmospheres of Democracy. Cambridge MA: MIT Press, 2005a, 994-1003. Introductory notes on an ecology of practices. Cultural Studies Review, Vol. 11, No1, 2005b, pp.183-196.

TATE MODERN. Good Feelings in Good Times, Roman Ondák, 2003 Disponível em: < http://www.tate.org.uk/art/artworks/ondak-goodfeelings-in-good-times-t1 1940/text- summary>. Acessado em: 20 de junho de Collecting the Performative, 2012. Disponível em: http://www.tate.org.uk/about/ projects/collecting-performative>. Acessado em: 20 de junho de 2015

TINOCO, Bianca Andrade. Performance e geração 80: resgates. 294 f., il. Dissertação (Mestrado em Artes)-Universidade de Brasília, Brasília, 2009 